\title{
КНЯЗЬЯ-КРЕСТИТЕЛИ БОЛГАРИИ И РУСИ: ПОИСК АНАЛОГИЙ
}

\section{А. А. Роменский}

Роменський О. О. Князі-хрестителі Болгарії та Русі: пошук аналогій. В статті порівнюються наративні образи правителів, що запровадили християнство в Болгарії та на Русі, аналізуються літературні топоси та обставини християнізації Східної Європи та Балкан. Виявлено спільні тенденції в діяльності та церковному пошануванні Св. Бориса Болгарського та Володимира Святославича.

Ключові слова: князь Борис; князь Володимир; Перше Болгарське царство; Русь; культ святих.

Роменский $\boldsymbol{A}$. $\boldsymbol{A}$. Князья-крестители Болгарии и Руси: поиск аналогий. В статье сравниваются нарративные образы правителей, утвердивших христианство в Болгарии и на Руси, анализируются литературные топосы и обстоятельства христианизации Восточной Европы и Балкан. Обнаружены общие тенденции в деятельности и церковном почитании Святых Бориса Болгарского и Владимира Святославича.

Ключевые слова: князь Борис; князь Владимир; Первое Болгарское царство; Русь; культ святых.

Romensky A. A. Princes-Baptists of Bulgaria and Rus: a Search for Analogies. The article compares the narrative images of rulers, which have approved Christianity in Bulgaria and Rus, analyzes the literary topoi and real circumstances of the Christianization of Eastern Europe and the Balkans. General trends were found in the activities and Church veneration of Sts. Boris of Bulgaria and Vladimir Svyatoslavich of Kiev.

Keywords: Prince Boris; Prince Vladimir; the First Bulgarian Empire; Rus; Cult of Saints.

Сведения об обширных политических, культурных и религиозных связях между государствами южных славян и Русью не оставляют сомнения в том, что взаимное влияние касалось и сферы почитания святых. Действительно, около середины XII в. формируется южнославянская редакция древнерусского Пролога, попавшая на Балканы к концу того же или к началу следующего века ${ }^{1}$. В Болгарии и Сербии распространялись жития святых, канонизированных на Руси, в том числе страстотерпцев Бориса и Глеба, князя Владимира, княгини Ольги, варягов-мучеников, Мстислава Великого ${ }^{2}$. Святые из балканских стран также были известны в русских княжествах (помимо широко распространенного культа общеславянских просветителей, равноапостольных Константина-Кирилла и Мефодия, чье наследие попало в Восточную Европу через болгарское посредство и в болгарской рецепции $)^{3}$. Так, памяти Св. Иоанна Рильского и Параскевы Тырновской сохранились в месяцеслове рубежа XIII-XIV вв., в прибавлении к Галицкому Четвероевангелию 1144 г. $^{4}$. В свою очередь, записи о русских святых имеются в Тырновском Евангелии 1273 г. (послужившем вероятным источником этих прибавлений), что иллюстрирует интенсивные контакты южных и восточных славян в сфере культа ${ }^{5}$. В литературе существует экзотическая гипотеза о том, что перенесение мощей Свв. Бориса и Глеба на Руси 2 мая 1115 г. было осуществлено не без влияния отмечавшейся в тот же день памяти Св. Бориса-Михаила Болгарского ${ }^{6}$. Не менее оригинальное предположение исследователей (прежде всего, М. Д. Приселкова, а также А. В. Карташева) о заимствовании князем Владимиром Святославичем церковной иерархии из Охрида в последние годы существования там независимого патриархата ныне можно считать окончательно опровергнутым ${ }^{7}$.

Тем не менее, креститель Руси не мог обойтись без кадров священнослужителей, подготовленных в Болгарии, и заимствованных там же богослужебных книг на старославянском языке. Специалисты считают, что князь Владимир Святославич получил в свое распоряжение библиотеку болгарских царей, переданную ему, вероятно, византийцами в ходе осуществленных, в том числе с помощью русов, войн против державы царя Самуила и его преемников ${ }^{8}$. Можно считать доказанным болгарское происхождение антологии патристики - «Изборника», переписанного на Руси для князя Святослава Ярославича в 
1073 г. (вероятны болгарские корни и второй древнейшей рукописной книги, «Изборника» 1076 г.) $)^{9}$. Не случаен интерес составителя ПВЛ к истории балканского славянского государства ${ }^{10}$. Согласно распространенной, хотя и весьма спорной, атрибуции, именно креститель Болгарии - князь Борис-Михаил - изображен на роскошных золотных миниатюрах рукописей Син. 262 и Чуд. 12. Первая из миниатюр сохранилась в рукописи Учительного Евангелия епископа Константина Преславского, в копии с болгарского оригинала ${ }^{11}$. На другой миниатюре из того же скриптория в рукописи «Слова Ипполита Римского о Христе и Антихристе», не исключено, также изображен кто-то из представителей болгарской правящей династии, держащий в левой руке модель храма. Впрочем, современные разыскания позволяют предположить, что на миниатюрах изображен князь-страстотерпец Борис Владимирович ${ }^{12}$. Тем не менее, духовные связи южных и восточных славян проявились уже в период христианизации последних. Целесообразно вновь сравнить образ князейкрестителей Болгарии и Руси в сохранившихся нарративах и уточнить особенности их почитания.

Специалисты неоднократно находили общие сюжетные линии в истории обращения к христианству князей Бориса и Владимира Святославича. Типологически они, несомненно, близки, и наличие ряда параллелей свидетельствует не только о сходной ситуации в государствах, недавно приобщенных к условному «Византийскому содружеству» и общих принципах и методах византийского миссионерства, но и о литературных топосах, стереотипных агиографических шаблонах, ярко проявляющихся в описании чуда крещения недавнего язычника ${ }^{13}$. Продолжатель Феофана свидетельствует о глубоком впечатлении, произведенном на болгарского правителя картиной Страшного суда, написанной в его охотничьем доме ромейским изографом - монахом Мефодием, не без миссионерского умысла ${ }^{14}$. Согласно рассказу Начальной летописи, князь русов также был поражен «запоной» со сценой Суда Господня, которую византийский «Философ» эффектно продемонстрировал под конец своей проповеди ${ }^{15}$. Как доказывают исследователи, эти свидетельства опирались на реальную практику ромейского миссионерства: проповедники предпочитали наочно демонстрировать сюжеты Священного Писания с помощью изобразительного искусства и, как ни странно, любили утомлять своих слушателей длинными историями из Ветхого Завета о сотворении мира и судьбах первых людей ${ }^{16}$. Монах Феодор Куфара, подобно Греку Философу в Начальной летописи, выступает наставником болгарского князя в основах веры, однако тот, как и Владимир впоследствии, не сразу приходит к христианству. Только постигший страну голод, осмысленный как «бич Божий», побуждает Бориса принять новую веру ${ }^{17}$. В случае с Владимиром Божья кара постигает князя за промедление в исполнении обета. Он обещает стать христианином под стенами Корсуня, получив за-

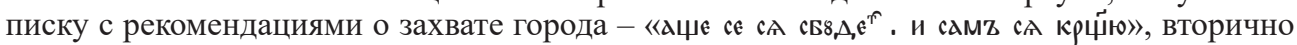
говорит византийским послам о намерении креститься в обмен на руку порфирородной принцессы; тем не менее, и после прибытия Анны ее будущий супруг, по сообщению Жития, еще «хоты вєzвъриє сотворити», за что и наказан слепотой и струпами, которые проходят лишь в крестильной купели ${ }^{18}$.

И в Болгарии, и на Руси существовала очевидная религиозная альтернатива, борьба за конфессиональное влияние христианских Востока и Запада (ярче проявившаяся на Балканах), что заставляет с меньшим скепсисом относиться к хрестоматийной фабуле религиозного диспута перед князем и «испытания вер ${ }^{19}$. Такие своеобразные соревнования между сторонниками не только разных Церквей, но и разных религий нередко проходили и впоследствии, стоит вспомнить описанные Гильомом де Рубруком дебаты представителей несториан, католиков, буддистов и мусульман при дворе монгольского кагана Менгу в середине XIII в. или соперничество мусульман и буддистов накануне принятия ислама ханом

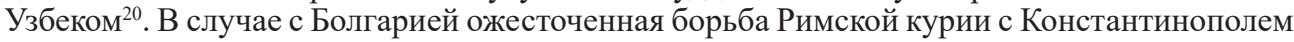
за души новообращенных язычников - подданных Бориса - долго велась с переменным успехом, и победа Византии в итоге (в 879-880 гг.) далеко не выглядит предопределенной. Используя выгодную политическую и религиозную конъюнктуру, князю Борису удалось добиться автокефалии Болгарской церкви, а при его внуке Петре произошел гораздо более впечатляющий успех - обретение статуса независимого патриархата в 927 г. $^{21}$.

Креститель Руси Владимир, несмотря на гораздо более выгодные стартовые позиции (родство с василевсами Македонской династии) и острую необходимость Византии в во- 
енно-политическом сотрудничестве, так и не смог повторить достижение болгарского коллеги и предшественника, но это случилось, как думается, вовсе не вследствие приверженности киевского князя к духовному единству с ромеями ${ }^{22}$. О сложности переговоров о статусе Русской Церкви свидетельствует задержка с учреждением ее организационной структуры. Ранее большинство исследователей относили ее формирование к периоду не позже 997 г., поскольку следующая после «Росии» в нотициях Константинопольского патриархата, Аланская митрополия, как считалось, появляется в источниках именно в это время (с открытием надписи из Сентинского храма 965 г., упоминающей о митрополите Феодоре и печати митрополита Игнатия середины X в., этот аргумент теряет силу) ${ }^{23}$. Новые исследования А. В. Назаренко позволяют оспорить это широко распостраненное мнение и отодвинуть хронологически образование митрополии в Киеве к последним годам княжения Владимира Святославича ${ }^{24}$. Вероятно, упоминаемый Титмаром Мерзебургским в 1018 г. архиерей, встречавший польского князя Болеслава после захвата им Киева, тождественен Феофилакту Севастийскому, первому достоверно известному предстоятелю митрополичьей кафедры на Руси ${ }^{25}$.

Нельзя исключать и возможности переговоров с Римом и Оттонами. Вопреки традиции, отраженной в Житии Петра Дамиани и Хронике Адемара Шабаннского ${ }^{26}$, мы не склонны считать Бруно Кверфуртского реальным крестителем Руси в конце X в., но все же сам факт его миссионерской и миротворческой миссии к печенегам при содействии киевского князя свидетельствует об активности Рима в Восточной Европе этого времени ${ }^{27}$. Таким образом, Русь, как и Болгария столетием раньше, оказалась на острие не только политических и дипломатических, но и религиозных противоречий.

Историю христианизации Болгарии, Сербии и Руси объединяет также и ее привязанность к последствиям политических договоренностей. Источники связывают крещение Бориса с результатами мирного соглашения, достигнутого с византийцами после военного конфликта 863 г. $^{28}$. По сообщению Продолжателя Феофана, архонт Борис отказался от военных намерений благодаря остроумию регентши, императрицы Феодоры ${ }^{29}$. Подобное соглашение было, по всей вероятности, оформлено между Владимиром и византийскими василевсами Василием II и Константином VIII в 988 г. на гораздо более выгодных для Руси условиях вследствие победы в Юго-Западной Таврике и острого кризиса внутри империи ${ }^{30}$. Сведения о крещении Сербии при Василии I Македонянине позволяют утверждать, что и оно сопровождалось борьбой за политические интересы держав и включением страны в сферу византийского влияния. По сообщению Константина Багрянородного, сербы и хорваты отправили послов к василевсу ромеев с просьбой о крещении и политическом подчинении; василевс послал василика с иереями, чтобы крестить их, а также поставил над ними архонтов из числа лиц, которых они сами выбирали ${ }^{31}$.

Распространенные агиографические топосы в нарративах о крещении Бориса и Владимира Святославича проявляются, например, в той роли, которая традиционно отведена праведным женщинам-христианкам - сестре болгарского правителя и новой супруге киевского князя, порфирородной Анне. Князья приобщаются к крещению во многом благодаря их увещеваниям, что в целом характерно для варварской периферии христианского мира в раннее средневековье ${ }^{32}$. В случае с Владимиром можно уверенно утверждать, что заслуги Анны не являются измышлением позднейшего киевского книжника - о ее роли в распространении христианства согласно говорят независимые друг от друга авторитетные современники - Яхъя Антиохийский и Титмар Мерзебургский ${ }^{33}$.

Характерна сконструированная постфактум связь повествований о святых князьях с кирилло-мефодиевской традицией. В Житии Климента Охридского сообщается о крещении Бориса самим равноапостольным Мефодием ${ }^{34}$. Составленное в XV в. «Сказание о русской грамоте», автор которого имел весьма смутные представления о реальных обстоятельствах крещения Руси, утверждает символическую связь между чудом обретения славянской письменности Св. Константином-Кириллом в Корсуне и обращением к вере Владимира Святославича в этом же византийском городе ${ }^{35}$. Иногда в поздних древнерусских источниках ромейский проповедник, излагающий князю ветхо- и новозаветную историю (с апокрифическими деталями), также именуется Кириллом ${ }^{36}$.

Восприятие крещения Владимира и Бориса в текстах парадоксально объединяет и фигура Патриарха Фотия. Фотий был автором пространного послания и нескольких пи- 
сем к правителю болгар, убеждая его ничем не поступаться ради сохранения целостности догматов христианской веры ${ }^{37}$. Именно Фотий анахронистически становится современником Крестителя Руси в церковном уставе Владимира и некоторых поздних летописях ${ }^{38}$. Остается не вполне ясным, отразился ли в этом анахронизме факт обращения верхушки русов в христианство после похода 860 г., сопровождавшийся, возможно, кратковременным установлением структуры Церкви во главе с архиепископом ${ }^{39}$. Возможно, сказалось и реноме Фотия как яркого противника Римской курии и защитника ромейской ортодоксии.

И Св. Борис Болгарский, и Св. Владимир Киевский выступают не только крестителями, но и просветителями в своих государствах. Борис-Михаил поощряет миссионерскую и литературную деятельность учеников Кирилла и Мефодия, Климента Охридского, Наума и Ангелария, что подготовило расцвет староболгарской письменности и культуры, особенно ярко проявившийся в правление его сына, Симеона Великого ${ }^{40}$. В Болгарии славянский литературный язык впервые стал официальным, а создание огромного корпуса текстов обогатило культуру всех славянских народов. Владимир Святославич, по сообщению Начальной летописи, инициировал развитие «учения книжного», заставляя детей «нарочитой чади» постигать грамоту ${ }^{41}$. Результаты образовательной реформы не замедлили сказаться: к началу XI в. относится древнейший из сохранившихся памятников письменности - Новгородский кодекс42; уже в следующем поколении древнерусских книжников появились авторы не только переводов, но и оригинальных литературных произведений.

Посмертное почитание первых христианских властителей Болгарии и Руси также развивалось в рамках во многом сходных тенденций. Вопрос о времени и обстоятельствах причтения Бориса-Михаила к лику святых остается спорным; отсутствует его полная служба и календарная память (за исключением упоминания в месяцеслове о подавлении князем восстания боилов-язычников в 866 г.), не сохранилось княжеского жития, а проблема его возможных фрагментов так бесспорно и не выяснена в литературе ${ }^{43}$. Не менее дискуссионна и проблема первоначального почитания князя Владимира, истоки которого можно проследить уже в XI в. Тем не менее, лишь к рубежу XIII-XIV вв. князь уверенно занимает место среди пантеона русских святых ${ }^{44}$. В Центральной и Восточной Европе утверждавшие христианство правители нечасто удостаивались церковного почитания, а путь к признанию их заслуг всегда был тернистым. Несмотря на это, огромное значение деятельности крестителя Болгарии и его коллеги на Руси не подлежит сомнению, что всегда будет привлекать к ним пристальное внимание исследователей.

${ }^{1}$ Лосева О. В. Жития русских святых в составе древнерусских Прологов XII - первой трети XV вв. М.: Рукописные памятники Древней Руси, 2009. С. 53-54. См.: Сперанский М. Н. К истории взаимоотношений русской и югославянских литератур // Известия отделения русского языка и словесности. 1923. Т. 26. С. 143-206; Mošin V. A. Slavenska redakcija Prologa Konstantina Mokisijskog u svjetlosti vizantijsko-slavenskih odnosa XII-XIII vijeka // Zbornik Historijskog Instituta Jugoslavenske Akademije. Zagreb, 1959. Т. 2. S. 17-68; Мошин B. A. О периодизации русско-южнославянских литературных связей X-XV вв. // Из истории русской культуры / Сост. А. Ф. Литвина, Ф. Б. Успенский. М.: Языки славянской культуры, 2002. С. 806-807; Турилов А. А. Древнерусские (восточнославянские) влияния на книжность южных славян // Православная энциклопедия (далее - ПЭ). М.: ЦНЦ «Православная энциклопедия», 2007. Т. 16. С. 162-171; Его же. Из истории русско-южнославянских книжных связей XII-XIII вв.: новое и забытое // Russica Romana. 2010. Vol. 17. C. 9-32; Его же. Забытые и малоизвестные факты из истории древнейшего перевода Пролога у южных славян (к проблеме «первого восточнославянского влияния») // Славяноведение. 2012. № 2. С. 16-17.

${ }^{2}$ Пичхадзе А. А., Ромодановская В. А., Ромодановская Е. К. Жития княгини Ольги, Варяжских мучеников и князя Владимира в составе Синайского палимпсеста (РНБ, Q.n.I.63) // Русская агиография. Исследования. Публикации. Полемика / [ред. Семячко С. А., Руди Т. В.]. СПб.: Дмитрий Буланин, 2005. Т. 1. С. 288-308; Лосева О. В. Жития русских святых.... С. 278-279.

${ }^{3}$ См.: Флоря Б. Н. Судьбы Кирилло-Мефодиевской традиции после Кирилла и Мефодия / Б. Н. Флоря, А. А. Турилов, С. А. Иванов. СПб.: Алетейя, 2000. С. 8-10.

${ }^{4}$ Турилов А. А. Две забытые даты болгарской церковно-политической истории IX в.: (К вопросу о формировании болгарского варианта церковного месяцеслова в эпоху Первого царства) // Турилов А. A. Slavia Cyrillomethodiana: Источниковедение истории и культуры южных славян и Древней Руси: Межславянские культурные связи эпохи средневековья. М.: Знак, 2010. С. 136-137. 
5 Лосева О. В. Русские месяцесловы XI-XIV вв. М.: Памятники исторической мысли, 2001. C. $82-83$.

${ }^{6}$ Георгиева Н. Към въпроса за почитанието на княз Борис I како светец // Кирило-Методиевски студии. София: Академично издательство „Проф. Марин Дринов“, 1991. Кн. 8. С. 187-188; Турилов А. А. Борис // ПЭ. М., 2003. Т. 6. С. 31.

${ }^{7}$ Приселков М. Д. Очерки по церковно-политической истории Киевской Руси X-XII вв. СПб., 1913. С. 36-43; Карташев А. В. Очерки по истории Русской Церкви. Париж: Ymca-Press, 1959. C. $158-163$.

${ }^{8}$ Poppe A. Christianisierung und Kirchenorganisation der Ostslawen in der Zeit vom 10 bis zum 13 Jahrhundert // Österreichische Osthefte. 1988. Bd. 30. S. 470-478; Литаврин Г. Г. Византия, Болгария, Древняя Русь. СПб.: Алетейя, 2001. С. 308-310.

${ }^{9}$ Динеков П. Н. Значение Изборника Симеона-Святослава 1073 г. в развитии болгарской культуры // Изборник Святослава 1073 г. М.: Наука, 1977. С. 273-279; Ševčenko I. Remarks on the Diffusion of Byzantine Scientific and Pseudo-Scientific Literature among the Orthodox Slavs // The Slavonic and East European Review. 1981. Vol. 59. № 3. P. 330-334; Lunt H. G. On the Izbornik of 1073 // Harvard Ukrainian Studies (далее-HUS). 1983. Vol. 7. Р. 360-361; Сохань П. С. До історії україно-болгарських зв'язків IX-XIV ст. // Софія Київська. Візантія. Русь. Україна. К., 2013. Вип. 3. С. 548.

10 Зыков Э. Г. Известия о Болгарии в Повести временных лет // Труды отдела древнерусской литературы. 1969. Т. 24. С. 48-53; Сохань П. С. До історії... С. 538.

${ }^{11}$ Popova O. S. Les miniatures russes du XI-e au XV-e siècle. Leningrad: Avrora, 1975. P. 26, ill. 9. Датировка миниатюр и атрибуция изображенных князей остаются спорными. Так, Е. В. Уханова считает, что обе рукописи, Син. 262 и Чуд. 12, созданы в киевском скриптории в последней четверти XI - начале XII вв., а миниатюры изображают русского святого князя-мученика Бориса Владимировича. Ее аргументы поддержали Э. С. Смирнова и А. С. Преображенский; таким образом, доминировавшая до сих пор в историографии «болгарская» версия атрибуции поколеблена. См.: Уханова E. B. Древнейшие изображения Св. князя Бориса. К истории библиотеки Владимира Мономаха // Борисо-Глебский сборник / Ред. К. Цукерман. Paris: ACHCByz, 2009. Вып. 1. С. 117-156; Смирнова Э. С. Ранние этапы иконографии святых князей Бориса и Глеба. Вопрос византийских образцов и сложения русской традиции // Борисо-Глебский сборник / Ред. К. Цукерман. Paris: ACHCByz, 2009. Вып. 1. С. 75-80; Преображенский А. С. Ктиторские портреты средневековой Руси. XI - начало XV вв. М.: Северный паломник, 2010. С. 335-340.

${ }^{12}$ Голышенко В. С. К вопросу об изображении князя в Чудовской рукописи XII-XIII вв. // Проблемы источниковедения. М.; Л., 1959. Т. 7. С. 391-415; Иванова В. Ктиторският образ в Ипполитовия сборник на Исторический музей в Москва // Археология. 1959. № 3/4. С. 1-23; Dujčev I. Slawische Heilige in der byzantinischen Hagiographie // Dujčev I. Medioevo byzantino-slavo. Roma: Edizioni di Storia e Letteratura, 1968. S. 216; см.: Вздорнов Г. И. Искусство книги в Древней Руси: Рукописная книга Северо-Восточной Руси XII-XV вв. М.: Искусство, 1980. С. 15-18; Турилов А. А. Борис // ПЭ. М.: ЦНЦ «Православная энциклопедия», 2003. Т. 6. С. 30-32; Пуико В. Г. Иллюминированная древнерусская книга XI-XIII вв. // Древняя Русь: вопросы медиевистики (далее - ДРВМ). 2001. № 3. С. 50; Попова О. С. Византийские и древнерусские миниатюры. М., 2003. С. 267. Другая интерпретация миниатюры: Преображенский A. C. Ктиторские портреты средневековой Руси. XI - начало XV вв. М.: Северный паломник, 2010. С. 332-340; Его же. Изображения святых в выходных миниатюрах русских рукописей XI-XIV веков // Международен научен симпозиум Византия и славяните. По случай 20-годишнината от създаването на Центъра за славяно-византийски проучвания „Иван Дуйчев“ към Софийския университет „Св. Климент Охридски“ (София, 12-14 май 2006 г.). София, 2011. Т. 96 на Годишник на Софийския университет „Св. Климент Охридски“. С. 371-377.

${ }^{13}$ Иванов С. А. Византийское миссионерство: можно ли сделать из «варвара» христианина? М.: Языки славянской культуры, 2003. С. 161-169.

${ }^{14}$ Theophanes Continuati libri I-IV // Corpus fontium historiae byzantinae / Ed. A. Kambylis. - Berolini: De Gruyter, 2015. Vol. 53. P. 232-234; Продолжатель Феофана. Жизнеописания византийских царей / Изд. подгот. Я. Н. Любарский. СПб.: Алетейя, 2009. С. 109-110.

15 Лаврентьевская летопись // ПСРЛ. Л.: Издательство АН СССР, 1928. Т. 1. Вып. 1. Стб. 106.

${ }^{16}$ Ševčenko I. Religious Missions Seen from Byzantium // HUS. 1988/1989. Vol. 12/13. P. 21-23.

${ }^{17}$ Theophanes Continuati libri I-IV. P. 232.

${ }^{18}$ См.: Лаврентьевская летопись // Полное собрание русских летописей (далее - ПСРЛ). Л.: Издательство АН СССР, 1926. Т. 1. Вып. 1. Стб. 109-110; Особое житие // Милютенко Н. И. Святой равноапостольный князь Владимир и крещение Руси. СПб.: Издательство Олега Абышко, 2008. С. 475.

${ }^{19}$ Гюзелев $B$. Княз Борис Първи. България през втората половина на IX в. София: Наука и изкуство, 1969. С. 178-208; Принятие христианства народами Центральной и Юго-Восточной Европы и крещение Руси / Отв.ред. Г. Г. Литаврин. М.: Наука, 1988. С. 239-241.

${ }^{20}$ Гильом де Рубрук. Путешествие в восточные страны // Путешествие в восточные страны Плано Карпини и Рубрука. М.: Государственное издательство географической литературы, 1957. С. 171- 
173; Юрченко А. Г. Хан Узбек: между империей и исламом. Структуры повседневности. СПб.: Евразия, 2012. С. 250-288.

${ }^{21}$ Принятие христианства народами Центральной и Юго-Восточной Европы. . С. 41-63; Литаврин Г. Г. Христианство в Болгарии в 927-1018 гг. // Христианство в странах Восточной, Юго-Восточной и Центральной Европы на пороге второго тысячелетия / Отв. ред. Б. Н. Флоря. М.: Языки славянской культуры, 2002. С. 141.

${ }^{22}$ См. противоположное мнение А.-Э. Тахиаоса: Taхиаос А.-Э. Н. Основные пункты влияния Византии на русскую культуру // Spicilegium Byzantino-Rossicum. Сборник статей к 80-летию членакорреспондента РАН И. П. Медведева. М.: Индрик, 2015. С. 285.

${ }^{23}$ Darrouzès J. Notitiae Episcopatuum ecclesiae Constantinopolitanae. P.: Institut Francais d'Études Byzantines, 1981. P. 333: 57, 681; Ibid. P. 335: 59, 701; cf.: Poppe A. Państwo i kościól na Rusi w XI wieku. Warszawa: Państwowe Wydawn. Naukowe, 1968. S. 28-30; Idem. The Original Status of the Old Russian Church // Acta Poloniae Historica. 1979. Vol. 39. Р. 20-26; Щапов Я. Н. Государство и Церковь в Древней Руси. М.: Наука, 1989. С. 28; Головко О. Б. Входження Русі до Pax Christiana Orthodoxa i формування християнської церковної організації у слов’ян Східної Європи (VIII-XI ст.) // Actes Testantibus. Ювілейний збірник на пошану Леонтія Войтовича / Відп. ред. М. Литвин. Львів: Інститут українознавства імені І. Крип'якевича НАН України, 2011. С. 248; Милютенко Н. И. Святой равноапостольный князь Владимир и крещение Руси. СПб.: Издательство Олега Абышко, 2008. С. 326-328. Об Аланской митрополии: Малахов С. Н. Алания и Византия: источниковедческие аспекты политических и церковных связей. М.: СЕМ, 2015. С. 31-33; Виноградов А. Ю. Очерк истории аланского

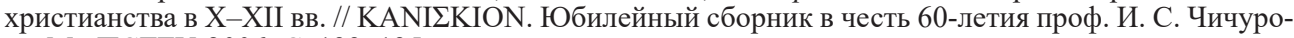
ва. М.: ПСТГУ, 2006. С. 133-135.

24 Доклад А. В. Назаренко «Учреждение Киевской митрополии: коррективы в свете новых данных» на конференции «Русь эпохи Владимира Великого: государство, церковь, культура», Москва 14-16.10. 2015

${ }^{25}$ Die Chronik des Bishofs Thietmar von Merseburg und ihre kohrveier Uberarbeitung / Herausgegeben von R. Holtzmann // Monumenta Germaniae Historica. Scriptores rerum Germanicarum in usum scholarum. Berlin: Weidmannsche Buchhandlung, 1935. Т. 9. S. 530. О Феофилакте Севастийском см.: Nicephorus Callistus. Historia ecclesiastica // Patrologiae cursus completus, series graeca. 1865. T. 146. Col. 1196; Honigmann E. Studies in Slavic Church History: IV. Theophylactos, the First Metropolitan of Russia? // Byzantion. 1944/45. Vol. 17. P. 148-158; Grumel V. Chronologie patriarchale au X $\mathrm{X}^{\mathrm{e}}$ siècle // Revue des etudes byzantines. 1964. № 22. P. 51-54; Poppe A. The Political Background to the Baptism of Rus: Byzantine-Russian Relations between 986-989 // Dumbarton Oaks Papers. 1976. Vol. 30. P. 204-206.

${ }^{26}$ Petrus Damiani. Vita beati Romualdi / A cura di G. Tabacco. Roma: Instituto storico italiano, 1957. P. 57-60; Ademar de Cabannes. Chronique. P., 1897. Р. 152-153; см.: Древняя Русь в свете зарубежных источников: Хрестоматия. М.: Русский фонд содействия образованию и науке, 2010. Т. 4. Западноевропейские источники / Сост., пер. и коммент. А. В. Назаренко. С. 88-90.

${ }^{27}$ CM.: List Brunona do króla Henryka / J. Karwasińska // Monumenta Poloniae Historica. Series Nova. Warszawa: Panstwowe Wydawnictwo Naukowe, 1973. T. 4. S. 98-100; Zakrzewski S. Bolesław Chrobry Wielki. Lwow: Wydawnictwo zakładu narodowego imienia Ossolińkich, 1925. S. 224; Poppe A. Spuscizna po Wlodzimierzu Wielkim. Walka o tron Kijowski 1015-1019 // Kwartalnik Historyczny. 1995. Rochnik 102. № 3-4. S. 13; Idem. Der Kampf um die Kiever Tronfolge nach dem 15 Juli 1015 // Forschungen zur osteuropäischen Geschichte. 1995. Bd. 50. S. 284-285; Поппэ A. В. Владимир Святой. У истоков церковного прославления // Факты и знаки. Исследования по семиотике истории. 2008. Вып. 1. С. 56, прим. 33; Его же. К биографии Святополка Окаянного // История: дар и долг. Юбилейный сборник в честь А. В. Назаренко. М.: Издательство Олега Абышко, 2010. С. 225-241; Фонт М. Пребывание Бруно Кверфуртского в Киеве - факты, вопросы, гипотезы // Studia Slavica Hungarica. 2013. Vol. 58. C. 43 .

${ }^{28}$ Принятие христианства народами Центральной и Юго-Восточной Европы... С. 45.

${ }^{29}$ Theophanes Continuati libri I-IV. P. 230.

${ }^{30} \mathrm{C}$. подробнее об этом: Роменский A. А. О месте и времени оформления русско-византийского соглашения в конце Х в. // ДРВМ. 2015. № 3. С. 154.

${ }^{31}$ Константин Багрянородный. Об управлении империей. М.: Наука, 1989. С. 114-115; Коматина П. Црквена политика Византије од краја иконоборства до смерти цара Василија І. Београд, 2014. C. 261-284.

32 Гузенко С. М. Психологічний феномен «євангелізуючих королев»: Київська Русь - християнський Захід і Схід // Давньоруське любомудріє: тексти і контексти / Упор. О. Вдовина, Ю. Завгородній. К.: Вид. дім «Києво-Могилянська Академія», 2006. С. 116-122.

${ }^{33}$ Розен В. Р. Император Василий Болгаробойца. Извлечения из летописи Яхъи Антиохийского // Записки Императорской Академии Наук. 1883. Т. 44. Приложение 1. С. 24; Die Chronik des Bischofs Thietmar. S. 486-487.

${ }^{34}$ Судьбы Кирилло-Мефодиевской традиции... С. 172. 
35 Пространно житие на Константин-Кирилл Философ // Климент Охридски. Събрани съчинения. София: Издателство на Българската академия на науките, 1973. Т. 3. С. 58-59; Живов В. M. Slavia Christiana и историко-культурный контекст Сказания о русской грамоте // Живов В. М. Разыскания в области истории и предыстории русской культуры. М.: Языки славянской культуры, 2002. С. 163166; Милютенко Н. И. Святой равноапостольный князь Владимир и крещение Руси. С. 312-320, $503-506$.

${ }^{36}$ Тверская летопись // ПСРЛ. СПб.: в типографии Леонида Демиса, 1863. Т. 15. С. 79; Новгородская Карамзинская летопись // ПСРЛ. СПб.: Дмитрий Буланин, 2002. С. 45; Новгородская четвертая летопись // ПСРЛ. СПб.: Типография Я. Башмакова, 1915. Т. 4. Ч. 1. Вып. 1. С. 61; Софийская первая летопись // ПСРЛ. - Л.: Издательство Российской академии наук, 1925. С. 50.

37 Писма на Патриарх Фотий // Грьцки извори за българската история. София: Издание на Българската академия на науките, 1961. Т. 4. С. 59-99.

38 Устав князя Владимира о десятинах, судах и людях церковных // Древнерусские княжеские уставы XI-XV вв. / Изд. Я. Н. Щапов. М.: Наука, 1976. С. 15, 16, 18, 19, 21; Летопись по Воскресенскому списку // ПСРЛ. М.: Языки русской культуры, 2001. Т. 7. Ч. 1. С. 313; Русский хронограф (редакции 1512 г.) // ПСРЛ. СПб., 1911. Т. 22. Ч. 1. С. 367; Патриаршая или Никоновская летопись // ПСРЛ. М.: Наука, 1965. Т. 9. С. 57.

${ }^{39}$ См.: Щапов Я. Н. Государство и Церковь в Древней Руси. М.: Наука, 1989. С. 192; Коматина П. Црквена политика Византије од краја иконоборства до смерти цара Василија I. Београд, 2014. С. 312-314.

40 Судьбы Кирилло-Мефодиевской традиции... С. 192-197; Гюзелев В. Княз Борис Първи... C. 344-379.

41 Лаврентьевская летопись. Стб. 118-119.

42 Зализняк А. А., Янин В. Л. Новгородский кодекс первой четверти ХІ в. - древнейшая книга Руси // Вопросы языкознания. 2001. № 5. С. 3-25.

${ }_{43}$ Турилов А. А. Две забытые даты болгарской церковно-политической истории... С. 124-125; Турилов A. А., Флоря Б. Н. Христианская литература у славян в середине Х - середине ХІ в. и межславянские культурные связи // Христианство в странах Восточной, Юго-Восточной и Центральной Европы на пороге второго тысячелетия. М.: Языки славянской культуры, 2002. С. 411.

${ }^{44}$ Поппэ А. В. Владимир Святой. У истоков церковного прославления // Факты и знаки. Исследования по семиотике истории. 2008. Вып. 1. С. 91-103. 